\title{
Chemical Attributes and Carbon Fractions in Serra de Itabaiana National Park
}

\author{
Audenis Fagner de Jesus Nascimento ${ }^{1}$ (i) 0000-0001-5932-9634 \\ Tácio Oliveira da Silva ${ }^{1}$ (in memoriam) \\ Renisson Neponuceno Araújo Filho² (1) 0000-0002-9747-1276 \\ Victor Casimiro Piscoya ${ }^{3}$ (1) 0000-0003-1875-9771 \\ Moacyr Cunha Filho ${ }^{3}$ (D) 0000-0002-3466-8143 \\ Alceu Pedrotti ${ }^{1}$ (1) 0000-0003-3086-8399
}

\begin{abstract}
This study aimed to assess soil chemical attributes, organic matter fractions and carbon stocks of forest in three different regeneration stages in the Serra de Itabaiana National Park, Sergipe. The study was conducted in three areas: open white sands, intermediate white sands, and closed white sands, with a history of differentiated degradation. Soil samples were collected at $0-20 \mathrm{~cm}$ depth for chemical characterization and for fractionation of soil organic matter and $\mathrm{C}$ stock. The open white sands obtained the best results regarding levels of macronutrients, total organic carbon, and total soil nitrogen, as well as higher carbon/nitrogen ratio compared with intermediate white sands and closed white sands, with such effects being attributed to recent exposure to fire. Carbon concentrations in humic fractions of organic matter were little influenced by different vegetation in regeneration, except the carbon fraction of humic acid, which is more sensitive to different management and soil usage.
\end{abstract}

Keywords: native vegetation, fertility, organic matter, sustainability.

\section{INTRODUCTION AND OBJECTIVES}

Soil organic matter (SOM) conservation has been used as an essential indicator of soil organic matter for its relationship with numerous chemical, physical and biological properties. Adequate levels of SOM in temperate and tropical ecosystems can benefit from increased soil fertility, as they minimize impacts on the environment through carbon (C) sequestration, reducing soil erosion and preserving biodiversity (Zhao et al., 2017).

Soil fertility is related to the molecular characteristics of the soluble alkaline fraction of organic carbon, the humic substances (HS). The fractions belonging to the humic substances are dynamic as they reflect changes in soil management. However, few studies on these substances do not confirm the influence of carbon on HS fractions regarding soil fertility (Rodrigues et al., 2017).

The presence of organic matter and its humid fraction may be compromised by specific anthropic actions such as fire, influencing the soil fertility. In forest ecosystems, the occurrence of fire has a lasting effect, both in the microbial composition as well as in the soil organic matter. These changes may interfere with all soil carbon dynamics (Araya et al., 2017).

There are studies on soil organic matter characteristics in other regions of Brazil, such as the capoeira areas under burning (Pessoa et al., 2012), and the soil in different organic production systems (Loss et al., 2011). However, these studies are still incipient in native areas in the Northeast region of Brazil, although it is possible to find studies determining total organic carbon and SOM fractions in native and cultivated areas in coastal soils (Pedra et al., 2012), but these studies are scarce in native areas in the state of Sergipe.

Therefore, this type of soil survey and diagnosis under native vegetation at different regeneration stages is necessary, as only two studies with vegetation surveys have been carried out until today (Dantas \& Ribeiro, 2010; White et al., 2013). This kind of research is an essential tool to evaluate soil quality

\footnotetext{
${ }^{1}$ Universidade Federal de Sergipe (UFS), São Cristóvão, SE, Brasil

${ }^{2}$ Universidade Federal do Tocantins (UFT), Gurupi, TO, Brasil

${ }^{3}$ Universidade Federal Rural de Pernambuco (UFRPE), Recife, PE, Brasil
} 
in different soil-vegetation uses and the impact caused by this type of improper burning practice.

The vegetation in the Serra de Itabaiana National Park contains tree species considered typical of the Brazilian savannas, such as Curatella americana (Dilleniaceae), Byrsonima coccolobifolia (Malpighiaceae), Vochysia lucida (Vochysiaceae), Tapirira guianensis (Anacardiaceae), Ouratea sp. (Ochnaceae), and Lafoensia sp. (Lythraceae), but this characteristic is insufficient to classify the vegetation as cerrado, and conditions such as a humid climate, sandy quartz soil, hydrography and its distance from the central cerrado are sufficient to differentiate these species from a common cerrado vegetation. Sandy and yellowish white sedimentary soils can be found in the eastern side of the Itabaiana and Comprida mountain ranges. The areas where the white sands are exposed support vegetation ranging between shrub-herbaceous and shrub-tree, according to the regeneration history of the areas (Dantas \& Ribeiro, 2010). The objective of this study was to evaluate the chemical attributes of the soil, as well as organic matter fractions and carbon stocks of forest in three different regeneration stages at the Serra de Itabaiana National Park, Sergipe.

\section{2. MATERIALS AND METHODS}

\subsection{Description of the study area}

The Serra de Itabaiana National Park is located between the Areia Branca and Itabaiana municipalities in the state of Sergipe, Northeast Brazil. This park covers a total area of 7966 ha and comprises three units: Cajueiro, Comprida and finally the Itabaiana mountain range, which is the largest. Its geographic coordinates are between latitudes and approximate longitudes of $10^{\circ} 40^{\prime} \mathrm{S}$ and $37^{\circ} 25^{\prime} \mathrm{W}$. The vegetation between the mouth of the Sergipe river and the northwest towards the three hills is composed of a narrow strip of open areas of the coastal restingas parallel to the coast, and fragmented forest remnants that cover the hills in the shape of an orange half, being characteristic of the morphoclimatic Atlantic forest domain (Dias et al., 2017).

The vegetation between the preservation area and the west is wild, with a mitigated caatinga that accompanies a complex of low mountain ranges, containing the three hills that compose the Park, until Bahia where the relief is flattened, and semi-arid vegetation becomes dominant (Ab'Saber, 1986; Vanzolini, 1986).

The region presents a tropical with dry summer climate and moderate surplus water in the winter, with a Thornthwaite (MI) rainfall index between -1.3 and 8.8 . The region is characterized by an average annual precipitation between 1,100 and $1,300 \mathrm{~mm}$ and average annual evapotranspiration of $800 \mathrm{~mm}$ (Vicente, 1998).
The soil class present in the Serra de Itabaiana National Park white sand areas corresponds to Psamment, which is the nomenclature of ancient dystrophic quartz sands. This type of soil is considered well drained, ranging between moderate and extremely acidic and it presents low natural fertility (Embrapa, 2013).

Three areas of white sands with a history of differentiated degradation were selected to carry out the study. The first area was called open white sands (OWS) located in the Comprida mountain range, which was affected by the last great fire in the Serra de Itabaiana National Park in 2005. This fire occurred in the same year that the Comprida mountain range was included in the Conservation Unit (a Brazilian organization gathering many protected areas), in which shrub and grass vegetation predominate; the second area called intermediate white sands (IWS) is located in the Serra de Itabaiana and it has been protected since 1978, but periodic fires occurred up to 1994; the third and last area is located near the Brazilian Institute of the Environment and Renewable Natural Resources (IBAMA) headquarters in the Serra de Itabaiana and it has not had considerable fire focuses for more than 30 years, including a more closed vegetation and greater size, and it is called closed white sands (CWS).

\subsection{Design, collection of samples and chemical characterization of soil}

Plots of $100 \mathrm{~m} \times 20 \mathrm{~m}$ were demarcated, being divided into 20 continuous plots of $10 \mathrm{~m} \times 10 \mathrm{~m}$, totaling 2,000 $\mathrm{m}^{2}$ in each of the three white sand sample areas outlined in the Serra de Itabaiana National Park. Soil samples were collected at a depth of $0-20 \mathrm{~cm}$ with the aid of a Dutch survey, following a transect of $100 \mathrm{~m}$ median to the plot.

Three samples were removed every 10 meters to compose a composite sample at $0-20 \mathrm{~cm}$ depth to form a repeat. The soil samples were dried in shade and air, then they were sieved in $2 \mathrm{~mm}$ mesh screens and homogenized, thus forming the air dry thin soil (ADTS) and the samples were prepared for determining the chemical attributes: $\mathrm{pH}$ (1:2.5), extractable $\mathrm{P}$ and $\mathrm{K}$ contents (Mehlich ${ }^{-1}$ extractor), $\mathrm{Ca}, \mathrm{Mg}, \mathrm{Al}, \mathrm{Al}+\mathrm{H}$, sum of bases (SB) (T), CEC at pH 7.0 (T), as well as the percentage of base saturation (V), total organic carbon (TOC), total soil nitrogen (TSN) by the Kjeldahl method, all determinations followed the methodology described by Donagema (2011).

\subsection{Chemical fractionation of organic matter}

The humic substances were separated for the chemical fractionation of the organic matter, according to the methodology adapted by Benites et al. (2003). The humic fractions were 
extracted based on solubility in alkali or acid. The carbon of the humic fractions was determined by wet oxidation following the Walkley-Black method (1934). The organic carbon (C) of the fulvic acid fraction (C-FAF), humic acid fraction (C-HAF), and humin (C-HUM), as well as the C-HAF/C-FAF and C-EA/CHUM, were calculated as (C-EA $=\mathrm{C}-\mathrm{FAF}+\mathrm{C}-\mathrm{HAF}$ ) (Benites et al., 2003). As the soil is treated with sandy soil, samples for soil density were collected, and soil density was determined using the methodology described by Donagema (2011), for soil with sandy granulometry.

The carbon stock in the sampled layer was estimated based on the expression: TOC $=(\mathrm{C} \times \mathrm{Ds} \times \mathrm{t}) / 10$, where TOC is the Total Organic Carbon stock in $\mathrm{g} \mathrm{kg}^{-1}$; Ds is the bulk density of the studied layer in $\mathrm{kg} \mathrm{dm}^{-3}$, and " $\mathrm{t}$ " is the layer thickness in $\mathrm{cm}$ (Cardoso et al., 2011).

\subsection{Statistical analysis}

The data were submitted to analysis of variance (ANOVA), and the means were compared by the Tukey's test at the 5\% probability level. The statistical program SISVAR was used for both study of variance and mean test (Ferreira, 2011).

\section{3. RESULTS AND DISCUSSION}

Regarding soil fertility, the open white sand area (OWS) presented higher values in absolute numbers of $\mathrm{K}^{+}, \mathrm{Ca}^{2+}$ and $\mathrm{Al}^{+3}$ (Table 1), as well as TOC and TSN (Table 2) compared with other areas. For the concentrations of potassium (K), magnesium $(\mathrm{Mg})$, and percentage of saturation by bases $(\mathrm{V})$, the significant superiority of the OWS and CWS areas was verified in relation to the IWS area (Table 1). The $\mathrm{Ca}^{2+}$ value in the OWS was higher in comparison with the CWS and IWS areas, differing significantly. According to some authors, the accumulation of ashes as a consequence of burning the vegetation increases the $\mathrm{Ca}^{2+}$ contents, mainly due to the rapid mineralization provoked by the fires (Rheinheimer et al., 2003).
The $\mathrm{pH}$ values in these areas (Table 1) ranged between 5.17 and 5.42, considered as medium acidity according to Costa et al. (2008) and Sobral et al. (2007). In the IWS area, which was susceptible to periodic fires, the $5.42 \mathrm{pH}$ was higher than the other areas studied. According to Batista et al. (1997), many substances in the form of oxides are released after burning the organic matter of the soil, with remaining carbonates usually presenting alkaline reaction, thus, increasing the $\mathrm{pH}$ of the soil. The exchangeable aluminum values obtained were between 0.13 and 0.28 , indicating low aluminum toxicity according to Larcher (2004). Based on these results, it is possible to establish a relationship between the $\mathrm{pH}$ and $\mathrm{Al}^{3+}$ values. We observed that the exchangeable aluminum values increased as the $\mathrm{pH}$ of the soil was more acidic. According to Slattery (1999), a higher concentration of $\mathrm{Al}$ occurs in acid soils, which is undesirable because of its toxicity to plants.

The potential acidity $(\mathrm{H}+\mathrm{Al})($ Table 1$)$ did not present a statistical difference between white sand areas. However, the $\mathrm{H}+\mathrm{Al}$ values in the IWS area were 1.26 , which is considered low, and presented values of 3.72 and 2.52 for the OWS and CWS, respectively, which are considered average according to Costa et al. (2008). Regarding SB, the highest values were found in the OWS area, which differed significantly from the IWS; similar behavior was obtained for the variables effective CEC ( $\mathrm{t}$ ) and CEC at $\mathrm{pH}$ 7.0. OWS and CWS presented higher levels of organic carbon in the soil, increasing thus effective CEC ( $\mathrm{t}$ ) and CEC at $\mathrm{pH} 7.0(\mathrm{~T})$. This increase can also be observed by Briedis et al. (2012), in which the raise in soil TOC increases potential and effective cation exchange capacity. Thus, changes in TOC support the number of negative charges in the soil.

In relation to the levels of phosphorus (P) in the soil, the three different areas presented no significant variation (Table 2), so that the mineralized phosphorus probably moved quickly to non-labile forms when not absorbed by plants (Novais \& Smyth, 1999).

Table 1. $\mathrm{pH}$ values, concentrations of potassium $\left(\mathrm{K}^{+}\right)$, calcium $\left(\mathrm{Ca}^{2+}\right)$, magnesium $\left(\mathrm{Mg}^{2+}\right)$, aluminium $\left(\mathrm{Al}{ }^{3+}\right)$, potential acidity $(\mathrm{H}+\mathrm{Al})$, Sum of bases (SB), effective CEC ( $\mathrm{t}$, CEC pH $7.0(\mathrm{~T})$ and percentage of bases saturation $(\mathrm{V})$ of Psamment under different stages of native vegetation in the Serra de Itabaiana National Park.

\begin{tabular}{|c|c|c|c|c|c|c|c|c|c|c|}
\hline \multirow{2}{*}{$\begin{array}{l}\text { Vegetation } \\
\text { Areas }\end{array}$} & pH & $\mathbf{K}$ & $\mathrm{Ca}$ & $\mathbf{M g}$ & Al & $\mathbf{H}+\mathbf{A l}$ & SB & $\mathbf{t}$ & $\mathbf{T}$ & V \\
\hline & (H2O) & \multicolumn{8}{|c|}{$\mathrm{cmol}_{\mathrm{c}} \mathrm{dm}^{-3}$} & $\%$ \\
\hline $\mathrm{OWS}^{1}$ & $5.17 \mathrm{a}^{2}$ & $0.004 a$ & $2.58 \mathrm{a}$ & $0.56 \mathrm{a}$ & $0.28 \mathrm{a}$ & $3.72 \mathrm{a}$ & $3.15 \mathrm{a}$ & $3.44 \mathrm{a}$ & $6.87 \mathrm{a}$ & $48.56 \mathrm{a}$ \\
\hline IWS & $5.42 \mathrm{a}$ & $0.002 b$ & $0.38 b$ & $0.01 b$ & $0.13 a$ & $1.26 \mathrm{a}$ & $0.38 b$ & $0.51 b$ & $1.64 \mathrm{~b}$ & $29.37 b$ \\
\hline CWS & $5.37 \mathrm{a}$ & $0,003 a$ & $1.15 b$ & $0.64 \mathrm{a}$ & $0.22 \mathrm{a}$ & $2.52 \mathrm{a}$ & $1.79 \mathrm{ab}$ & $2.02 \mathrm{ab}$ & $4.32 \mathrm{ab}$ & $47.59 \mathrm{a}$ \\
\hline Average & 5.32 & 0.003 & 1.37 & 0.40 & 0.21 & 2.50 & 1.77 & 1.99 & 4.28 & 41.84 \\
\hline
\end{tabular}

${ }^{1}$ OWS: open white sands; IWS: intermediate white sands; CWS: closed white sands; ${ }^{2}$ Measures followed by the same letter in the columns do not differ by Tukey's test at the $5 \%$ probability level. 
Table 2. Concentrations of extractable phosphorus (P), total organic carbon (TOC), total soil nitrogen (TSN) and the values of the C/N ratio and carbon stocks (CS) of Psamment under different stages of native vegetation in the Serra de Itabaiana National Park.

\begin{tabular}{|c|c|c|c|c|c|}
\hline \multirow{2}{*}{ Vegetation areas } & $\mathbf{P}$ & TOC & NT & $\mathbf{C} / \mathbf{N}$ & CS \\
\hline & $\mathrm{mg} \mathrm{kg}^{-1}$ & \multicolumn{2}{|c|}{$\mathrm{g} \mathrm{kg}^{-1}$} & $\begin{array}{c}--- \\
--\end{array}$ & $\mathrm{Mg} \mathrm{ha}^{-1}$ \\
\hline OWS $^{1}$ & $24.47 \mathrm{a}^{2}$ & $12.84 \mathrm{a}$ & $0.35 \mathrm{a}$ & $36.09 \mathrm{a}$ & $36.60 \mathrm{a}$ \\
\hline IWS & $24.69 a$ & $2.92 b$ & $0.14 \mathrm{~b}$ & $19.20 \mathrm{~b}$ & $9.72 b$ \\
\hline CWS & $36.27 \mathrm{a}$ & $7.72 \mathrm{ab}$ & $0.32 \mathrm{ab}$ & $23.18 \mathrm{~b}$ & $23.28 \mathrm{~b}$ \\
\hline Average & 28.48 & 7.83 & 0.27 & 26.16 & 24.20 \\
\hline
\end{tabular}

${ }^{1}$ OWS: open white sands; IWS: intermediate white sands; CWS: closed white sands; ${ }^{2}$ Measures followed by the same letter in the columns do not differ by Tukey's test at the $5 \%$ probability level.

According to Sobral et al. (2007), these levels of P in soil are considered adequate in Table 2. According to Galang et al. (2010), an increase in P availability is generally observed after burning due to the accumulation of ashes in the soil, although no significant differences were found. However, according to Knicker (2007), these effects tend to disappear in the medium term due to rainfall leaching, resulting in concentrations that may even be lower as observed in this study, where the concentrations in OWS and IWS areas were lower than CWS.

For the total organic carbon (TOC) (Table 2), a significant difference was found between the OWS and IWS areas, since the CWS area did not differ in relation to the other areas. These values can be explained due to OWS having been burned in a more recent period than the IWS, and such increase may be associated with the raise in the leaf fall and vegetal remains caused by the burning, as evidenced by Pessoa et al. (2012).

TSN values (Table 2) followed the same trend as TOC, where the area of closed white sand did not show a significant difference in relation to the other sands. These data corroborate the observation made by Haridasan (2008), showing that the total raise of $\mathrm{N}$ decreases in relation to the total organic carbon content. Only OWS and IWS presented a significant difference between them, with the first being superior to the second. According to Rheinheimer et al. (2003), this difference generally occurs because the most recent burning of dead vegetation promotes catalysis in the mineralization process, thereby enriching the soil as observed in OWS; while the TSN in IWS was already susceptible to losses by percolation and volatilization in months posterior to the burning.

For the different areas, the $\mathrm{C} / \mathrm{N}$ ratio (Table 2) varied between 9.72 and 36.60, being significantly higher in OWS compared to IWS and CWS areas. This high $\mathrm{C} / \mathrm{N}$ ratio in OWS is possibly causing slow decomposition of soil organic residues, especially when compared to the IWS and CWS area, which explains the TOC accumulation in the OWS area.

Regarding the carbon stock values in the soil, one can note that the OWS area was statistically superior to the other areas, indicating that the burning action may have increased the $\mathrm{C}$ stock in the soil, and possibly influencing the soil density. As a result, its relevance in the results is higher (Table 2). The predominance of grasses in OWS may have supported this higher C stock in the soil. Bernoux et al. (1999) observed that the replacement of native vegetation by pasture favored an increase in the soil C stock. This process is also related to the lower decomposition rate of grasses, favoring a greater contribution of carbon.

The carbon content in the different fractions of the soil humic substances (Table 3 ) in the white sand areas was also analyzed, being: fulvic acid fraction (C-FAF), the humic acid fraction (C-HAF) and humin (C-HUM).

These humic substances of the SOM showed changes in carbon content in the fulvic acid fraction (C-FAF) ranging between 0.244 and $0.721 \mathrm{~g} \mathrm{~kg}^{-1}$. However, no statistical difference was found $(p<0.05)$ between the white sand areas (Table 3). Although no significant differences were observed, the CWS area presented higher values of this fraction, demonstrating the faster regeneration of this area since C-FAF are richer structures in carboxylic groups than C-FAH (Dick et al., 2009).

The OWS area differed statistically from the IWS in carbon humic acid fraction (C-HAF), with OWS being higher. According to Cunha et al. (2001), humic fractions tend to be sensitive to disturbances caused by land use and vegetation systems, which may explain the difference between the OWS and IWS areas.

The values corresponding to carbon in the humin fraction (C-HUM) were higher when compared to C-FAF and C-HAF in all areas. Pessoa et al. (2012) also found higher mean values for carbon in the humin fraction in their evaluation of the distribution of humic fractions in the Northeast region of Brazil. Higher carbon values in the humin fraction are often evidenced in research about humic substances in tropical soils (Araújo et al., 2011; Fontana et al., 2010). According to Knicker et al. (2007), wildland fires changes the distribution of humic compartments of soil organic matter, causing increases in C-HUM concentration in detriment to C-FAF and C-HAF. 
Table 3. C concentration of humic fractions of soil organic matter under vegetation with different regeneration stages in the Serra de Itabaiana National Park, Sergipe.

\begin{tabular}{cccccc} 
& & & & & \\
Vegetation Areas & & C-HAF & C-HUM & C-HAF / C-FAF & C-EA/ C-HUM \\
\cline { 2 - 6 } & & $\mathbf{g ~ k g}^{-1}$ & & ---- & $0.655 \mathrm{a}$ \\
OWS & $0.244 \mathrm{a}^{3}$ & $0.520 \mathrm{a}$ & $1.157 \mathrm{a}$ & $0.18 \mathrm{a}$ & $0.203 \mathrm{a}$ \\
IWS & $0.023 \mathrm{a}$ & $0.046 \mathrm{~b}$ & $0.450 \mathrm{a}$ & $3.15 \mathrm{a}$ & $0.526 \mathrm{a}$ \\
CWS & $0.721 \mathrm{a}$ & $0.265 \mathrm{ab}$ & $1.017 \mathrm{a}$ & 2.31 & 0.461 \\
Average & 0.329 & 0.277 & 0.875 & & \\
\hline
\end{tabular}

${ }^{1}$ OWS: open white sands; IWS: intermediate white sands; CWS: closed white sands; ${ }^{2} \mathrm{C}-\mathrm{FAF}$ : carbon in fulvic acid fraction; C-HAF: carbon in humic acid fraction; C-HUM: carbon in humin; C-EA: C-FAF+C-HAF; ${ }^{3}$ Measures followed by the same letter in the columns do not differ by Tukey's test at the $5 \%$ probability level.

The C-HUM levels did not differ between white sand areas. However, the highest concentrations of C-HUM were found in OWS and CWS. The OWS values can be explained because part of the humic acid fraction is transformed into humin in areas that have been burned, since the soil is composed of additional inputs of ligninrich materials from the incomplete burning of the biomass (Araya et al., 2017).

The C-HAF/C-FAF ratio did not show significant effect among the different white sand areas (Table 3). The OWS and CWS presented values higher than 1 in absolute numbers, indicating a predominance of humic acid in the soil in relation to the fulvic acid fraction. The C-EA/C-HUM ratio presented values below 1 in all areas, indicating the superiority of the humin fraction in the soil in relation to other fractions. Furthermore, one can state that the more labile part of C, C-FAF, and C-HAF may have been depleted in depth or suffered a microbial attack; a possible fact since the sandy soil does not offer any protection to native organic matter. Corroborating with Guimarães et al. (2013), C-FAF and C-FAH/C-HUM increases information on the loss of SOM in the soil profile.

\section{CONCLUSIONS}

The OWS and CWS areas presented the highest concentrations of exchangeable bases, CEC, TOC and TN content in the soil.

The carbon concentrations in the humic acid fraction were more sensitive to different soil managements and uses.

In general, the possible presence of more recalcitrant plant material because of the presence of fire and low decomposition rate in the OWS area favored the higher carbon content in the soil.

\section{ACKNOWLEDGEMENTS}

To the professor and adviser Tácio Oliveira da Silva (in memoriam) for collaborating effectively in all phases of construction of the work.

\section{SUBMISSION STATUS}

Received: 13 Dec. 2017

Accepted: 6 Mar. 2019

Associate editor: Marcos Gervásio Pereira

(1) 0000-0002-1402-3612

\section{CORRESPONDENCE TO}

Audenis Fagner de Jesus Nascimento Universidade Federal de Sergipe (UFS), Av. Marechal Rondon, s/n, Jardim Rosa Elze, CEP 49100-000, São Cristóvão, SE, Brasil e-mail: audenis_fagner@yahoo.com.br

\section{REFERENCES}

Ab'Saber AN. Ecossistemas continentais. Porto Alegre: Associação dos Geógrafos Profissionais do Rio Grande do Sul; 1986.

Araújo EAD, Ker JC, Mendonça ES, Silva IR, Oliveira EK. Impact of forest-pasture conversion on stocks and dynamics of soil carbon and humic substances in the Amazon. Acta Amazonica 2011; 41(1): 103-114. 10.1590/S0044-59672011000100012

Araya SN, Fogel ML, Berhe AA. Thermal alteration of soil organic matter properties: a systematic study to infer response of Sierra Nevada climosequence soils to forest fires. Soil 2017; 3(1): 31-39. 10.5194/soil-3-31-2017

Batista AC, Reissmann CB, Soares RV. Efeitos da queima controlada sobre algumas propriedades químicas do solo em um povoamento de Pinus taeda no município de Senges - PR. Floresta 1997; 27(12): 59-70. 10.5380/rf.v27i12.2298

Benites VM, Madari B, Machado PLOA. Extração e fracionamento quantitativo de substâncias húmicas do solo: um procedimento simplificado de baixo custo. Comunicado Técnico 16. Rio de Janeiro: Embrapa Solos; 2003.

Bernoux M, Feigl BJ, Cerri CC, Geraldes APA, Fernandes SAP. Carbono e nitrogênio em solo de uma cronossequência de floresta tropical-pastagem de Paragominas. Scientia Agrícola 1999; 56(4): 777-783. 10.1590/S0103-90161999000400003

Briedis C, Moraes Sá JC, Caires EF, Navarro JF, Inagaki TM, Oliveira Ferreira AO. Carbono do solo e atributos de fertilidade em resposta à calagem superficial em plantio direto. Pesquisa Agropecuária Brasileira 2012; 47(7): 1009-1016. 10.1590/S0100-204X2012000700018 
Cardoso EL, Silva MLN, Silva CA, Curi N, Freitas DAF. Estoques de carbono e nitrogênio em solo sob florestas nativas e pastagens no bioma Pantanal. Pesquisa Agropecuária Brasileira 2011; 45(9): 1028-1035.

Costa MCG, Gilvan BF, Araújo AM. Apostila do curso de interpretação de análises de solo e recomendação de calagem e adubação no estado de Roraima. Documentos 8. Boa Vista: Embrapa Roraima; 2008.

Cunha TJF, Macedo JR, Ribeiro LP, Palmieri F, Freitas PL, Aguiar AC. Impacto do manejo convencional sobre propriedades físicas e substâncias húmicas de solos sob cerrado. Ciência Rural 2001; 31(1): 27-36. 10.1590/S0103-84782001000100005

Dantas TVP, Ribeiro AS. Estrutura populacional de Kielmeyera rugosa Choisy (Clusiaceae) no Parque Nacional Serra de Itabaiana, Estado do Sergipe. Acta Scientiarum 2010; 32(2): 141-146. 10.4025/ actascibiolsci.v32i2.5127

Dias DM, Pagotto MA, Pereira TC, Ribeiro AS. Tree structure and seasonality of the canopy cover in forested and open vegetation in 'Serra de Itabaiana' National Park, Sergipe state, Brazil. Ciência Florestal 2017; 27(2): 719-729. 10.5902/1980509827757

Dick DP, Novotny EH, Dieckow J, Bayer C. Química da matéria orgânica do solo. In: Melo VF, Alleoni LRF, editors. Química e mineralogia do solo. Viçosa: SBCS; 2009. p. 1-68.

Donagema GK, Campos DB, Calderano SB, Teixeira WG, Viana JM, editors. Manual de métodos de análise de solo. 2nd ed. Rio de Janeiro: Embrapa Solos; 2011

Empresa Brasileira de Pesquisa Agropecuária - Embrapa. Sistema Brasileiro de Classificação de Solos. 3rd ed. Rio de Janeiro: Embrapa Solos; 2013.

Ferreira DF. Sisvar: A computer statistical analysis system. Ciência e Agrotecnologia 2011; 35(6): 1039-1042. 10.1590/ S1413-70542011000600001

Fontana A, Brito RJ, Pereira MG, Loss A, Benites, VM. Caracterização de substâncias húmicas da camada superficial do solo sob diferentes coberturas vegetais. Magistra 2010; 22(1): 48-55.

Galang MA, Markewitz D, Morris LA. Soil phosphorus transformations under forest burning and laboratory heat treatments. Geoderma 2010; 155(3-4): 401-408. 10.1016/j.geoderma.2009.12.026

Guimarães DV, Gonzaga MIS, Silva TO, Silva TL, Silva Dias N, Matias MIS. Soil organic matter pools and carbon fractions in soil under different land uses. Soil and Tillage Research 2013; 126(1): 177-182. 10.1016/j.still.2012.07.010

Haridasan M. Nutritional adaptations of native plants of the Cerrado biome in acid soils. Brazilian Journal of Plant Physiology 2008; 20(3): 183-195. 10.1590/S1677-04202008000300003

Knicker H. How does fire affect the nature and stability of soil organic nitrogen and carbon? A review. Biogeochemistry 2007; 85(1): 91-118. 10.1007/s10533-007-9104-4

Larcher W. Ecofisiologia vegetal. São Carlos: RIMA; 2004.
Loss A, Pereira MG, Schultz N, Anjos LHC, Silva, EMR. Frações orgânicas e índice de manejo de carbono do solo em diferentes sistemas de produção orgânica. Idesia 2011;29(2): 11-19. 10.4067/ S0718-34292011000200002

Novais RF, Smyth TJ. Fósforo em solo e planta em condições tropicais. Viçosa: Universidade Federal de Viçosa; 1999.

Pedra WN, Pedrotti A, Silva TO, Macedo FL, Silva Gonzaga MI. Estoques de carbono e nitrogênio sob diferentes condições de manejo de um Argissolo Vermelho Amarelo, cultivado com milho doce nos tabuleiros costeiros de Sergipe. Semina 2012; 33(6): 2075-2090. 10.5433/1679-0359.2012v33n6p2075

Pessoa PMA, Duda GP, Barros RB, Freire MBGS, Nascimento CWA, Metri CM. Frações de carbono orgânico de um latossolo húmico sob diferentes usos no agreste brasileiro. Revista Brasileira de Ciência do Solo 2012; 36(1): 97-104. 10.1590/S0100-06832012000100011

Rheinheimer DS, Santos JCP, Fernandes VBB, Mafra AL, Almeida JA. Modificações nos atributos químicos de solo sob campo nativo submetido à queima. Ciencia Rural 2003; 33(1): 49-55. 10.1590/ S0103-84782003000100008

Rodrigues M, Rabelo FHS, Castro HAD, Roboredo D, Carvalho MACD, Roque CG. Changes in chemical properties by use and management of an oxisol in the amazon biome. Revista Caatinga 2017; 30(2): 278-286. 10.1590/1983-21252017v30n202rc

Slattery WJ, Conyers MK, Aitken RL. Soil pH, aluminium, manganese, and lime requirement. In: Peverill KI, Sparrow LA, Reuter DJ, editors. Soil analysis: an interpretation manual. Melbourne: CSIRO; 1999. p. 103-128.

Sobral LF, Viegas PRA, Siqueira OJW, Anjos JL, Barreto MCV, Gomes JBV. Recomendações para o uso de corretivos e fertilizantes no estado de Sergipe. Aracaju: Embrapa Tabuleiros Costeiros; 2007.

Vanzolini PE. Paleoclimas e especiação em animais da América do Sul tropical. Estudos Avançados 1992; 6(15): 41-65. 10.1590/ S0103-40141992000200003

Vicente A, Araújo GMM, Lírio Jr GP, Santos SC. Descrição parcial e preliminar dos hábitats da Serra de Itabaiana, Sergipe. Publicações Avulsas do Centro Acadêmico Livre de Biologia 1997; 1: 7-21.

Walkley A, Black IA. An examination of the Degtjareff method for determining soil organic matter and a proposed modification of the chromic acid titration method. Soil Science 1934; 37(1): 29-38.

White BLA, Ribeiro AS, Ribeiro GT, Souza RM. Building fuel models and simulating their surface fire behavior in the "Serra de Itabaiana" national park, Sergipe, Brazil. Floresta 2013; 43(1): 27-38. 10.5380/rf.v43i1.28034

Zhao J, Chen S, Hu R, Li Y. Aggregate stability and size distribution of red soils under different land uses integrally regulated by soil organic matter, and iron and aluminum oxides. Soil and Tillage Research 2017; 167: 73-79. 10.1016/j.still.2016.11.007 